\title{
Human papilloma virus in neoplastic and non-neoplastic conditions of the external eye
}

\author{
Zeynel A Karcioglu, Tawfik M Issa
}

\begin{abstract}
Aim-Human papilloma virus (HPV) types 16 and 18 have been associated with neoplastic conditions of the conjunctiva. However, the presence of this virus has not been reported in non-neoplastic disorders of the external eye nor has it been studied in normal conjunctival tissues.

Methods-Ninety six paraffin embedded tissue specimens with neoplastic and nonneoplastic lesions and 19 conjunctiva samples free from overt disease were studied for HPV types 16 and 18 positivity with the polymerase chain reaction.

Results-HPV types 16 and 18 DNA were identified in $57 \%$ of in situ squamous cell carcinoma, in $55 \%$ of invasive squamous cell carcinoma, in $20 \%$ of climatic droplet keratopathy, in $35 \%$ of scarred corneas, and in $32 \%$ of normal conjunctival tissue obtained during routine cataract extractions.

Conclusion-These findings indicate that HPV types 16 and 18 are detectable with the polymerase chain reaction not only in epithelial neoplasms of the ocular mucous membrane but also in non-neoplastic lesions as well as in apparently healthy conjunctiva.
\end{abstract}

(Br F Ophthalmol 1997;81:595-598)

Many DNA viruses including human papilloma virus (HPV) have been found to play significant roles in the induction of human malignancies. ${ }^{1-4}$ Approximately $80 \%$ of genital tumours harbour HPV. ${ }^{2}$ Other tumours, such as squamous cell carcinoma of the lung, larynx and upper respiratory tract, and oral mucosa have also been associated with HPVs. ${ }^{3}$ Evidence exists for the oncogenic potential of $\mathrm{HPV}$, particularly types 16 and $18 .{ }^{45}$ In many body sites including the oral mucosa, tongue, upper respiratory tract, and cervix normal appearing tissues have been found to react positively with the HPV 16 and 18 primers. $^{6-9}$ Histopathologically normal appearing regional lymph nodes from patients with cervical carcinoma revealed HPV 16 or 18 DNA in $50 \%$ of the cases. ${ }^{10}$

HPV types 16 and 18 have been documented in dysplastic and neoplastic lesions of the conjunctiva. ${ }^{11-13}$ However, few studies have evaluated the association of HPV 16 and 18 in non-neoplastic disorders of the external eye. The scarcity of such investigations prompted us to analyse the presence of HPV 16 and 18 in climatic droplet keratopathy (chronic actinic keratopathy) and injury related corneal scars as well as in clinically normal conjunctiva obtained during cataract surgery. We studied climatic droplet keratopathy because this entity appears to be caused by similar environmental factors that lead to epibulbar carcinoma. Posttraumatic corneal scars were evaluated to determine whether a non-neoplastic lesion of the ocular surface tissues would increase the likelihood of tissue harbouring HPV. The frequency of detectable HPV in the nonneoplastic conditions and normal conjunctiva was compared with the HPV positivity of in situ and invasive squamous cell carcinoma specimens.

\section{Patients and methods}

Specimens from 115 patients, 69 males $(60 \%)$ and 46 females $(40 \%)$ were included in this study. Haematoxylin and eosin sections from each specimen were examined histopathologically to confirm the diagnosis. Fourteen specimens with conjunctival squamous cell carcinoma in situ, 31 specimens with invasive squamous cell carcinoma, 20 specimens with climatic droplet keratopathy, 31 scarred corneas, and 19 specimens of normal appearing conjunctiva were included (Table 1).

CELL CULTURE AND DNA SAMPLES

CaSki and HeLa human cell lines were grown in Delbecco's modified eagle medium (DMEM) supplemented with $10 \%$ fetal calf serum (FCS) (Gibco-BRL, USA). CaSki cells contain 600 copies of HPV 16 while HeLa cells contain 10-50 copies of HPV 18, integrated in their respective genomes. ${ }^{2}$ Sample preparation for DNA extraction was performed as described. ${ }^{10}$

POLYMERASE CHAIN REACTION

The polymerase chain reaction (PCR) primers used in this study (Table 2) were synthesised by Integrated DNA Technologies, Inc, USA. Thermal cycler PCR System 480 and the Perkin-Elmer GeneAmp PCR reagent were supplied by Perkin-Elmer Cetus, USA.

The suitability of the extracted DNA for PCR amplification in each specimen was confirmed by successful amplification of a 110 bp fragment of the $\beta$ globin using $\mathrm{PCO} 3$ and PCO 4 primers $^{14}$ and $1 \mu \mathrm{g}$ DNA as a template. The conditions of PCR protocol were as described by Saiki et al. ${ }^{14}$ The positive control was DNA extracted from normal blood lymphocytes while the negative control contained all PCR reaction mixture except the DNA template.
Accepted for publication 18 March 1997 
Table 1 Summary of HPV types 16 and 18 DNA positivity in 115 specimens

\begin{tabular}{lllllr}
\hline Groups findings & $\begin{array}{l}\text { In situ SCC } \\
(n=14)\end{array}$ & $\begin{array}{l}\text { Invasive SCC } \\
(n=31)\end{array}$ & $\begin{array}{l}\text { CDK } \\
(n=20)\end{array}$ & $\begin{array}{l}\text { Corneal scar } \\
(n=31)\end{array}$ & $\begin{array}{l}\text { Conjunctiva } \\
(n=19)\end{array}$ \\
\hline $\begin{array}{l}\text { Mean age (years) } \\
\text { Sex: }\end{array}$ & 66 & 60 & 66 & 43 & 63 \\
$\quad$ Male & $10(71 \%)$ & $17(55 \%)$ & $14(70 \%)$ & $19(61 \%)$ & $9(47 \%)$ \\
$\quad$ Female & $4(29 \%)$ & $14(45 \%)$ & $6(30 \%)$ & $12(39 \%)$ & $10(53 \%)$ \\
HPV 16 & 0 & $4(13 \%)$ & $1(5 \%)$ & $4(13 \%)$ & $3(20 \%)$ \\
HPV 18 & $4(29 \%)$ & $6(19 \%)$ & $1(5 \%)$ & $6(19 \%)$ & $3(20 \%)$ \\
HPV 16+ 18 & $4(29 \%)$ & $7(23 \%)$ & $2(10 \%)$ & $1(3 \%)$ & 0 \\
Total HPV & $8(57 \%)$ & $17(55 \%)$ & $4(20 \%)$ & $11(35 \%)$ & $6(32 \%)$ \\
\hline
\end{tabular}

SCC $=$ squamous cell carcinoma $\mathrm{CDK}=$ climatic droplet keratopathy.

For HPV DNA detection, nested PCR was performed. In the first PCR, $1 \mu \mathrm{g}$ of sample DNA was used as a template with the outer primer, while in the second PCR, $2 \mu \mathrm{l}$ of the first PCR products were used as a template with specific inner primers for HPV 16 and 18, as shown in Table 2, following PCR cycle conditions described by Nawa et al. ${ }^{10}$

For nested PCR, $2 \mu \mathrm{l}$ of the first PCR was used as a template with specific inner primers to amplify segments of different lengths in each HPV as described by Nawa et al. ${ }^{10}$ Forty cycles were performed as follows: 30 seconds at $94^{\circ} \mathrm{C}$, 30 seconds at $55^{\circ} \mathrm{C}$, and 2 minutes at $70^{\circ} \mathrm{C}$; in the last cycle the extension step was increased to a total of 7 minutes.

The chosen primers applied in this study were able to detect one cell of HeLa in 10000 lymphocytes using DNA extracted from formalin fixed HeLa cells and lymphocytes. These primers were also shown to be sufficiently sensitive to detect $0.01 \mathrm{fg}$ of cloned HPV 16 and $18 .^{10}$

DNA from both HeLa and CaSki cells was used as the positive control while no DNA was added to the PCR reaction tube for the negative control. Precautions to avoid possible sources of contamination were followed as described by McDonnell et al. ${ }^{12}$

VISUALISATION OF PCR PRODUCTS

After PCR amplification, a $10 \mu \mathrm{l}$ aliquot of the reaction mixture was electrophoresed on $2 \%$ agarose gel (Perkin-Elmer, USA). Bands were visualised by ethidium bromide staining. Amplification of DNA bands of the appropriate size were identified by comparison with Gelmarker (Research Genetics, Inc, USA) and PhiX 174 RF DNA/Hae III fragments (Pharmacia Biotech, USA).

Table 2 Primer and probe sequences used in nested polymerase chain reaction (modified from Nawa et $a l^{10}$ )

\begin{tabular}{|c|c|c|c|}
\hline & Sequence 5'- 3' & Location & Product length \\
\hline Outer ${ }^{\star}$ & $\begin{array}{l}\text { ACCGAAAACGGTTGAACCGAAAACGGT } \\
\text { AATAATGTCTATATTCACTAATT }\end{array}$ & - & $307 \mathrm{bp}$ \\
\hline \multicolumn{4}{|c|}{ ( } \\
\hline HPV 16 & $\begin{array}{l}\text { ATGTTTCAGGACCCACAGGA } \\
\text { CCTCACGTCGCAGTAACTGT }\end{array}$ & $\begin{array}{l}104-123 \\
208-227\end{array}$ & $124 \mathrm{bp}$ \\
\hline HPV 18 & $\begin{array}{l}\text { ATGGCGCGCTTTGAGGATCC } \\
\text { GCATGCGGTATACTGTCTCT }\end{array}$ & $\begin{array}{l}106-125 \\
274-293\end{array}$ & $188 \mathrm{bp}$ \\
\hline \multicolumn{4}{|l|}{ Probe: } \\
\hline HPV 16 & $\begin{array}{l}\text { CACAGTTATGCACAGAGCTGCAAACAAC } \\
\text { TATACATGAT }\end{array}$ & $141-180$ & - \\
\hline HPV 18 & $\begin{array}{l}\text { GAACTGAACACTTCACTGCAAGACATAG } \\
\text { AAATAACCTG }\end{array}$ & $151-190$ & \\
\hline
\end{tabular}

${ }^{\star}$ Consensus primers for E60RF of HPV 16 and 18.

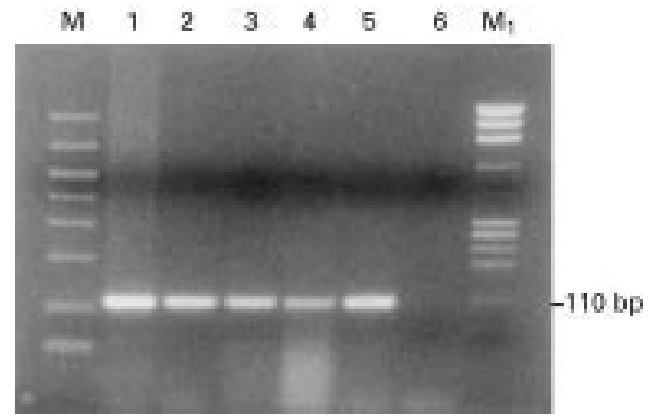

Figure 1 Detection of $\beta$ globin gene. Ethidium bromide stained $2 \%$ agarose gel showing $\beta$ globin gene amplification (110 bp product) following PCR amplification using PCO3/PCO4 primer and $1 \mu \mathrm{g}$ of DNA as a template from the following samples: lane 1, positive control (normal blood lymphocytes); lane 2, invasive squamous cell carcinoma (SCC); lane 3, in situ SCC; lane 4, corneal scar; lane 5, conjunctiva; lane 6, negative control (no DNA); $M$, GelMarker; $M_{1}$, PhiX 174 RF Hae III marker.

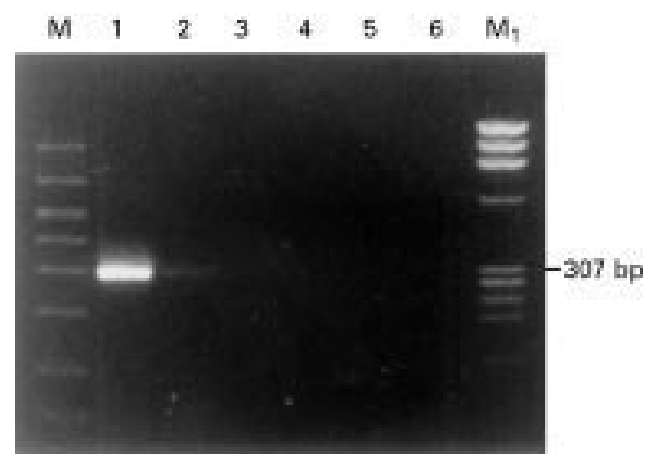

Figure 2 First PCR amplification of HPV DNA: consensus primer for E6 ORF of HPV 16 and 18 was used as outer primer along with $1 \mu \mathrm{g}$ of DNA as a template (307 bp product) from the following samples: lane 1, positive control for HPV 16 (CaSki cell DNA); lane 2, positive control for HPV 18 (HeLa cell DNA); lane 3, conjunctiva; lane 4, invasive squamous cell carcinoma (SCC); lane 5, in situ SCC; lane 6, negative control (no DNA); M, GelMarker; $M_{1}$, PhiX 174 RF Hae III marker.

SOUTHERN BLOT ANALYSIS

The PCR amplified products were electrophoresed on $2 \%$ agarose gel; then the gel was equilibrated in $0.25 \mathrm{~N} \mathrm{HCl}$ for 10 minutes. Then Southern transfer was conducted using Gene Screen plus membrane (NEN Research Products, USA) and $0.4 \mathrm{~N} \mathrm{NaOH}$ as the transfer solution. The membrane was hybridised with HPV 16 and HPV 18 specific probes (Table 2) labelled with the use of the ECL 3'-oligolabelling System (Amersham). Signal generation was done using Amersham Signal Generation System (Amersham), and the resulting chemiluminescence was detected using Hyperfilm-ECL (Amersham) following the Amersham protocol.

\section{Results}

All of the DNA samples used in this study were found to be positive for $\beta$ globin amplification (Fig 1). Figure 2 demonstrates the first PCR amplified DNA product using HPV outer primer. Nested PCR with inner primers for HPV 16 and 18 are depicted in Figures 3 and 4 respectively.

Human papilloma virus 16 and 18 DNA were present in four $(29 \%)$ of 14 specimens in the carcinoma in situ group. In addition, four others 


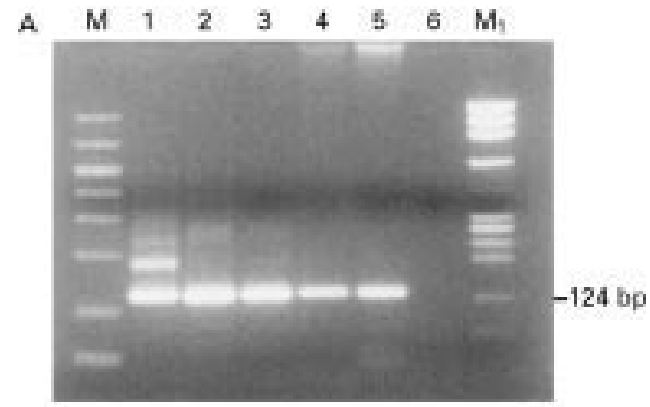

B

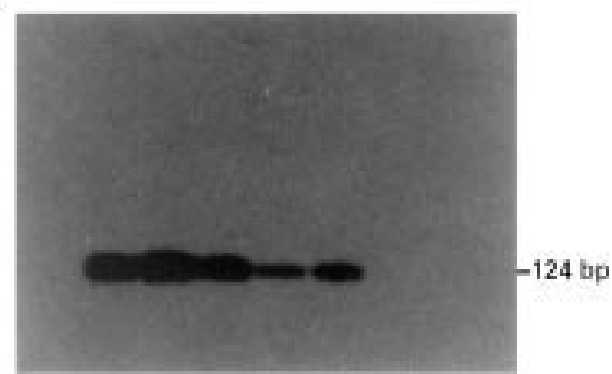

Figure 3 Detection of HPV 16 DNA. HPV 16 specific inner primer was used along with $2 \mu$ of the first $P C R$ reaction mixture as a template. (A) Analysis of the amplification DNA products on $2 \%$ agarose gel stained with ethidium bromide (124 bp product). (B) Southern blot analysis of the amplification DNA products hybridised with non-radioactive labelled HPV 16 specific

oligonucleotide probe for the following samples: lane 1, positive control (CaSki cell DNA); lane 2, conjunctiva; lane 3, conjunctiva; lane 4, invasive squamous cell carcinoma (SCC); lane 5, in situ SCC; lane 6, negative control (no DNA); M, GelMarker; M, PhiX 174 RF Hae III marker.

revealed HPV 18 DNA alone (29\%); no HPV 16 DNA alone could be identified in this group.

In the invasive squamous cell carcinoma group (31 specimens), HPV 16 DNA and HPV 18 DNA were identified in four (13\%) and six $(19 \%)$ specimens respectively. In addition, seven others $(23 \%)$ revealed HPV DNA of both types 16 and 18 together.

In the climatic droplet keratopathy group (20 specimens) HPV DNA was identified in two specimens, one (5\%) was type 16 and the other one $(5 \%)$ was type 18 . In addition, two $(10 \%)$ specimens revealed HPV DNA positivity with combined types 16 and 18 in this group. The HPV positivity in this group was $20 \%$. Histopathologically, only one specimen out of 20 revealed dysplastic epithelial changes in addition to climatic droplet keratopathy; this specimen was negative for HPV.

In the corneal scar group (31 specimens) HPV 16 and HPV 18 DNA was identified in four $(13 \%)$ and six $(19 \%)$ specimens, respectively. In addition, one (3\%) revealed positivity for HPV 16 and 18 DNA. Although not a single case with dysplastic changes was seen in this group, the overall positivity of HPV was $35 \%$.

In the conjunctival tissue control group six $(32 \%)$ of 19 specimens revealed positivity for HPV DNA.

\section{Discussion}

This study confirms reports of an association between conjunctival dysplastic/neoplastic

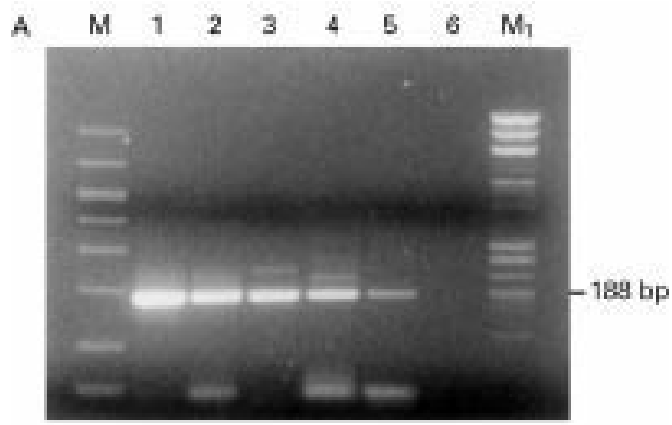

B

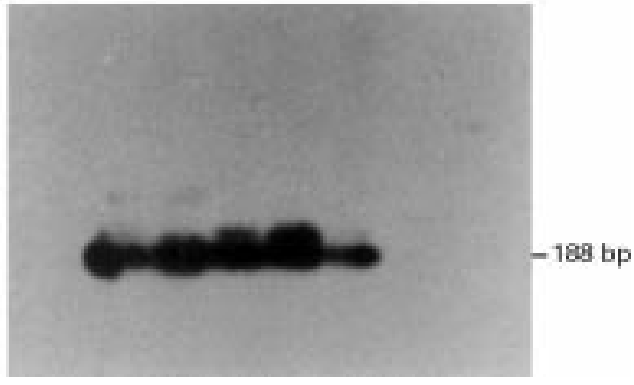

Figure 4 Detection of HPV 18 DNA. HPV 18 specific inner primer was used along with $2 \mu$ l of the first PCR reaction mixture as a template. (A) Analysis of the amplification DNA products on $2 \%$ agarose gel stained with ethidium bromide (188 bp product). (B) Southern blot of the amplification products hybridised with non-radioactive labelled HPV 18 specific oligonucleotide probe for the following samples: lane 1, positive control for HPV 16 (HeLa cell DNA); lane 2, conjunctiva; lane 3, invasive squamous cell carcinoma (SCC); lane 4, invasive SCC; lane 5, in situ SCC; lane 6, negative control (no DNA); M, GelMarker; $M_{1}$, PhiX 174 RF Hae III marker.

change and HPV, although the HPV prevalence is higher in conjunctival neoplasms. With PCR, HPV can be detected in the conjunctiva and cornea in a significant number of patients with non-neoplastic lesions as well as in normal conjunctiva. The presence of HPV under these conditions raises the possibility that HPV may not cause conjunctival neoplasms, but be merely a secondary invader. Many aspects of the presence of HPV in the external eye remain unanswered (including its transmission to this site, its prevalence in different disorders, and its oncogenic potential) and warrant further investigation.

In the eye, HPV DNA has not been studied in normal tissues nor has it been detected in specimens of conjunctival papilloma, naevus, melanoma, and pterygium. ${ }^{11}{ }^{12}{ }^{15}$ Other studies reported positive HPV type 16 surface antigens in pterygia but antigens for types 6,11 , and 18 were absent. ${ }^{16}$ An evaluation of the oncogenic role of HPV in conjunctival squamous dysplasia and neoplasia requires that different nonneoplastic external ocular lesions and normal conjunctiva be investigated.

Epidemiological and histopathological findings strongly suggest that ultraviolet radiation is a major factor in the development of dysplastic and neoplastic changes in the conjunctiva and cornea. ${ }^{17} \mathrm{McD}$ onnell and coworkers felt that ultraviolet exposure alone cannot explain the development of conjunctival neoplasia in their series. ${ }^{12}$ However, it is noteworthy that 25 of $35(71.4 \%)$ of their 
neoplastic specimens also had solar elastotic changes. ${ }^{12}$ Although 21 (84\%) of those specimens were positive for HPV 16 DNA, all six pterygia in the same study were negative. Conceivably, the neoplastic development is triggered by multiple interacting factors. For example, an interaction between ultraviolet light and HPV appears to be an oncogenic stimulus in epidermodysplasia verruciformis, a disorder in which multiple verrucous lesions develop into papillary carcinomas in sun exposed skin. ${ }^{4}{ }^{18} 19$ Since carcinomas in epidermodysplasia verruciformis contain different types of HPV, epidermodysplasia verruciformis is a convincing example of interactions between two oncogenic stimuli-namely, HPV and ultraviolet light. ${ }^{19} 20$

Another factor to consider in the development of conjunctival neoplasms is chronic inflammation due to various infectious agents. The oncogenic effect of chronic inflammation has long been studied, and the theory that a role of chronic inflammation exists in the genesis of neoplasia is supported with epidemiological evidence in cervical and oral cancers. ${ }^{7122}$ This is another issue to be considered in the development of conjunctival neoplasia in an environment like Saudi Arabia where external eye infections and trachoma have been common until recently. Ocular surface microtrauma has also been considered as an aetiological factor in conjunctival carcinogenesis. ${ }^{23-25}$

Like conjunctival epithelial neoplasms, climatic droplet keratopathy is considered to be caused by ultraviolet light exposure but the two conditions rarely develop in the same eye. ${ }^{26-29}$

Normal conjunctival specimens, many of which had actinic changes, revealed $32 \%$ positivity with HPV types 16 and 18. It is noteworthy that the incidence of conjunctival mucosa HPV positivity in our series is similar to HPV positivity reported in normal oral mucosa by Jalal and coworkers. ${ }^{6}$

The authors gratefully acknowledge Dr A Al-Ahdal for providing human cell lines CaSki and $\mathrm{HeLa}, \mathrm{Mr}$ Bernard Andres, RMT(AMT) for his technical assistance, and Dr Gordon K Klintworth for his invaluable comments and guidance during the conduct and publication of this work.

1 Levine AJ. Oncogenes of DNA tumor viruses. Cancer Res 1988;48:493-6.

2 Howley PM. The role of papillomavirus in human cancer In: De Vita VT, Hellman, Rosenberg, eds. Important advances in oncology. Philadelphia: Lippincott, 1987:55-73.

3 zur Hausen $H$. Human papillomaviruses and their possible role in squamous cell carcinoma. Curr Top Microbiol Immunol 1977;78:1-30.

4 Pfister H, Gassenmaier A, Nurnberger F, Stuttgen G. Human papilloma virus 5-DNA in a carcinoma of an epidermodysplasia verruciformis patient infected with various human papillomavirus types. Cancer Res 1983;43: 1436-41.
5 zur Hausen H. Papillomaviruses in human cancer. Cancer 1987;59:1692-6.

6 Jalal H, Sanders CM, Prime SS, Scully C, Maitland NJ. Detection of human papilloma virus type $16 \mathrm{DNA}$ in oral squames from normal young adults. F Oral Pathol Med 1992;21:465-70.

7 Maitland NJ, Cox MF, Lynas C, Prime SS, Meanwell CA, Scully C. Detection of human papillomavirus DNA in biopsies of human oral tissue. Br f Cancer 1987;56:245-50.

8 Veress G, Konya J, Csiky-Meszaros T, Czegledy J, Gergely L. Human papillomavirus DNA and anti-HPV secretory IgA antibodies in cytologically normal cervical specimens. 7 Med Virol 1994;43:201-7.

9 Chan MK, Lau KM, Tsui Y, Wong FW, Huang DP. Human papillomavirus infection in Hong Kong Chinese woman with normal and abnormal cervix-detection by PCR method on cervical scrapes. Gynecol Oncol 1993;60:21723.

10 Nawa A, Nishiyama Y, Kikkawa F, Kawai M, Mano H, Goto $\mathrm{S}$, et al. Detection of human papillomaviruses from histologically normal lymph nodes of Japanese cervical cancer patients by nested polymerase chain-reaction assay. Int 7 Cancer 1993;53:932-7.

$11 \mathrm{McDonnell} \mathrm{JM,} \mathrm{Mayr} \mathrm{AJ,} \mathrm{Martin} \mathrm{WJ.} \mathrm{DNA} \mathrm{of} \mathrm{human} \mathrm{pap-}$ illomavirus type 16 in dysplastic and malignant lesions of the conjunctiva and cornea. N Engl f Med 1989;320:14426.

$12 \mathrm{McD}$ onnell JM, McDonnell PJ, Sun YY. Human papillomavirus DNA in tissues and ocular surface swabs of patients with conjunctival epithelial neoplasia. Invest Ophthalmol Vis Sci 1992;33:184-9.

13 Alcocer CE, Scull JJ, Martins MC, et al. The presence of human papilloma virus in association with epithelial neoplasia of the conjunctiva. Invest Ophthalmol Vis Sci 1996;37:S625.

14 Saiki RK, Gelfand DH, Stoffel S, Scharf SJ, Higuchi R, Horn GT, et al. Primer-directed enzymatic amplification of DNA with a thermostable DNA polymerase. Science 1988; 239:487-91.

15 Adachi W, Nishida K, Shimizu A, et al. Amplification of HVP DNA in the conjunctiva in ocular surface disease. Invest Ophthalmol Vis Sci 1995;36:S1026.

16 Dolmetsch AM, Alcocer CE, Scull JJ, et al. The presence of human papilloma virus in pterygia. Invest Ophthalmol Vis Sci 1996;37:S43.

17 Lee GA, Hirst LW. Ocular surface squamous neoplasia. Surv Ophthalmol 1995;39:429-50.

18 Arends MJ, Wyllie AH, Bird CC. Papillomaviruses and human cancer. Hum Pathol 1990;21:686-98.

19 Orth G, Farve M, Breitburd F, et al. Epidermodysplasia verruciformis: a model for the role of papillomaviruses in human cancer. In: Essex M, Todaro, zur Hausen H, eds. Viruses in naturally occurring cancers. New York: Cold Spring Harbor Laboratory; 1980:259-82.

20 Lee GA, Williams G, Hirst LW, Green AC. Risk factors in the development of ocular epithelial dysplasia. Ophthalmology 1994;101:360-4.

21 Rotkin ID. A comparison review of key epidemiological studies in cervical cancer related to current searches for transmissible agents. Cancer Res 1973;33:1353-67.

22 Parashari A, Singh V, Gupta MM. Significance of inflammatory cervical smears. APMIS 1995;103:273-8.

23 Ash JE, Wilder HC. Epithelial tumors of the limbus. Am 7 Ophthalmol 1942;25:926-32.

24 Pizzarello LD, Jakobiec FA. Bowen's disease of the conjunctiva: misnomer. In: Jakobiec FA, ed. Ocular and adnexal tumors. Birmingham, AL: Aesculapius, 553-71.

25 Sivalingam V, Shields CL, Shields JA, Pearah JD. Squamous cell carcinoma of the conjunctiva associated with benign mucous membrane pemphigoid. Am f Ophthalmol 1990; 22:106-9.

26 Taylor HR. Aetiology of climatic droplet keratopathy and pterygium. Br f Ophthalmol 1980;64:154-63.

27 Johnson GJ. Aetiology of spheroidal degeneration of the cornea in Labrador. Br f Ophthalmol 1981;65:270-83.

28 Huaman AM, Griggs WC. Climatic droplet keratopathy: a survey among ophthalmic patients. Mid East $\mathcal{F}$ Ophthalmol 1994;2:154-62.

29 Klintworth GK. Proteins in ocular disease. In: Garner A, Klintworth GK, eds. Pathobiology of ocular disease: a dynamic approach. 2nd ed. chapter 32, New York: Marcel Dekker, 1994:973-1032. 